\title{
Influence of chloride threshold value in service life prediction of reinforced concrete structures
}

\author{
S MAHIMA $^{1}$, P V P MOORTHI ${ }^{2}$, A BAHURUDEEN ${ }^{3, *}$ and ATHIRA GOPINATH ${ }^{3}$ \\ ${ }^{1}$ Department of Civil Engineering, Indian Institute of Technology, Kanpur, India \\ ${ }^{2}$ Department of Civil Engineering, Indian Institute of Technology, Bombay, India \\ ${ }^{3}$ Department of Civil Engineering, Birla Institute of Technology and Science, Pilani, India \\ e-mail: bahurudeen.civil@gmail.com
}

MS received 27 September 2017; revised 2 February 2018; accepted 20 February 2018; published online 26 June 2018

\begin{abstract}
Extensive studies have been reported on the development of service-life prediction of reinforced concrete structures in the last two decades. Service life of a reinforced concrete structure is dependent on the corrosion process, specifically chloride threshold value. Chloride threshold value is a distinctive property and is dependent on several factors such as the supplementary cementitious material used, presence of surface cracks, water to binder ratio, type of steel reinforcement, exposure conditions, measurement methods, etc. Although chloride threshold value is an influential parameter in service-life prediction, a definitive chloride threshold value considering these factors is not reported in the existing literature and standards. Moreover, values adopted in many analytical tools for service life predictions based on the type of steel reinforcement alone are not appropriate and leads to inaccurate calculations. There is a gap in the available literature in understanding the selection of suitable chloride threshold values to be adopted for a specific system. Therefore, it is imperative to study the variation of chloride threshold value with exposure conditions as well as other influencing parameters, to achieve proper service life prediction. In the paper, several influencing parameters on chloride threshold value and its significance on prediction method are comprehensively reviewed. Moreover, suitable recommendations are highlighted for Indian and international standards at the later part of the study.
\end{abstract}

Keywords. Durability; corrosion; service life; concrete; chloride threshold value; supplementary cementitious materials.

\section{Introduction}

Reinforced concrete (RC) structures exposed to aggressive environment undergoes rapid deterioration and leads to a reduction in service life. World statistics show that about $3 \%$ of world's gross domestic product (GDP) i.e., US\$ 2.2 trillion (2010) is lost due to premature deterioration and corrosion of concrete structures [1]. Reliability of concrete and RC structures can be ensured through accurate prediction of service life, which is influenced by several deteriorating factors.

Service life prediction of any concrete structure is a manifold process, directly related to its durability and deterioration. Proper service life estimation requires stringent assessment of durability characteristics of concrete and RC structures. In order to ensure reliability in the prediction of service life, parameters that highly influence the service life of the structures were tested using performance testing and specifications. The performance parameters used for concrete and RC structures can be classified based on the deterioration

*For correspondence characteristics such as physical, chemical and electrochemical parameters. For instance, chemical characteristics such as calcium hydroxide content, characteristics of supplementary cementitious materials, the degree of hydration, pozzolanic reaction, $\mathrm{pH}$ of concrete, chloride diffusion coefficient and chloride migration coefficient are found to influence the chloride threshold level of reinforced concrete. Although many factors influence the chloride threshold value, a single value based only on steel type is considered in the standards. This practice is inappropriate and often leads to grossly wrong estimations of chloride threshold value. A comprehensive review of the influencing parameters of chloride threshold and suitable recommendations for practicing standards is imperative to achieve proper service life prediction.

\section{Deterioration: electro-chemical imbalance}

Corrosion is the gradual deterioration of a metal due to its reaction with the surroundings. Chloride-induced corrosion does not begin until a stabilized chloride threshold is reached in the concrete matrix. Corrosion of RC structures 
is highly influenced by the microstructural properties of the concrete. For example, a higher electrical resistivity of the concrete prevents electron transfer between anode and cathode resulting in a longer initiation period. Further, concrete cured properly with low w/c ratio results in lesser permeability and reduced diffusion of corrosion causing agents. Initiation of corrosion may be attributed to carbonation or chloride ion ingress, two major corrosioncausing agents. Corrosion mechanism involved depends mainly on the type of corrosive agent. The type of corrosion mechanism involved determines the period of propagation, which directly relates to the service life of RC structures.

\subsection{Process of depassivation: effect of chloride ion ingress}

Depassivation of reinforcements in RC structures is caused either by carbonation or chloride ion ingress. Hydration process in concrete leads to the formation of $\mathrm{Ca}(\mathrm{OH})_{2}$ and increases the alkalinity of the pore solution. This high alkalinity in concrete shields the reinforcement from corrosion. Both carbonation and chloride ion ingression reduces the alkalinity and thus activate the depassivation process in reinforcements.

Corrosion process due to chloride ion ingress is a complex physicochemical process involving the diffusion of chloride ions into concrete through the aqueous pore solution according to Fickian diffusion law [2, 3]. The chloride ions present in the pore solution called 'free chlorides' can directly result in corrosion, unlike bound chlorides that need to be mobilized by external processes to initiate corrosion [4]. By the chemical process of adsorption and binding, chloride ions in the aqueous pore solution are taken by the concrete solid phase. In general, compared to the carbonation process, corrosion due to chloride ingress is a slower process due to the necessity of fully or partially saturated pore structure. Based on the electrolytes present in the interstices of concrete and $\mathrm{pH}$ level, ionic interactions take place between the anode and cathode, referred to as 'half-cell reactions'. Investigative analysis for the calculation of chloride ion ingress was specified by Fick's second law of diffusion. The process of interaction of chloride with the solid phase of concrete involves binding of chlorides with hydration products formed during the hydration process. Moreover, the formation of an electrical double layer around the solid surface because of the cation movement also plays an important role in the corrosion process. Many researchers have conducted experimental and analytical studies to determine the exact relationship between chloride ion ingress and corrosion. Pereira and Hegedus (1984) developed a partial differential equation to find out the chloride diffusion coefficient by using coupled Langmuirian and Fickian diffusion, for fully saturated concrete [3]. This model was later extended and proven experimentally, by relating chloride diffusion with the deterioration of RC structures [4]. Corrosion initiation time i.e., the time required for the chloride level to reach the chloride threshold value for initiation of depassivation around the rebar can be estimated [5]. The corrosion propagation time, however, was found to be strongly influenced by the presence of water and Oxygen.

Uncertainties still prevail in the calculation of chlorideinduced corrosion and its influence on service life prediction [5-8]. Zhu et al emphasized the need for using a combination of carbonation mechanism and chloride ingress mechanism to be incorporated into service-life prediction models [9]. Although several studies have been carried out to find out the combined effect of chloride ingress and carbonation, the scientific community still has not reached consensus to whether it accelerates or decelerates corrosion [10-27]. Mix proportions and the type of admixtures significantly influence the diffusion coefficient of chloride ions. Several researchers conducted experiments to assess chloride ingress in combination with simultaneous carbonation [19-30]. The experimental outcomes showed that the chloride ion ingress is increased when the concrete is carbonized resulting in the higher release of chloride ions in the pore solution due to the reaction between Friedel's salt and carbon dioxide. The reaction is given by Equation (1).

$$
\begin{aligned}
& 3 \mathrm{CaO} \cdot \mathrm{Al}_{2} \mathrm{O}_{3} \cdot \mathrm{CaCl}_{2} \cdot 10 \mathrm{H}_{2} \mathrm{O}+3 \mathrm{CO}_{2} \\
& \quad \rightarrow 3 \mathrm{CaCO}_{3}+2 \mathrm{Al}(\mathrm{OH})_{3}+\mathrm{CaCl}_{2}+7 \mathrm{H}_{2} \mathrm{O}
\end{aligned}
$$

The above process significantly increases the free chloride ion concentration and indirectly the diffusion of chloride ions.

\subsection{Evolution of service life prediction models and influence of chloride threshold value}

Quantification of uncertainty in probabilistic service life prediction can be achieved by comparing the predicted data with measured data. Service life prediction models evolved and used for the prediction from 1970's to 1990's had used Fick's second law of diffusion. After several critics and severe analysis from a number of researchers, a direct error function was incorporated, as given in equation (2).

$$
C(x, t)=C_{i}+\left(C_{s}-C_{i}\right) \operatorname{erfc}\left(\frac{x}{2 \sqrt{\left(t-t_{\exp }\right) D_{c}}}\right)
$$

Until 1990, surface chloride concentration and diffusion coefficient were considered constant. Diffusion coefficient was believed to be a material dependent property. The diffusion coefficient and surface chloride concentration variation were predicted by laboratory exposure conditions [31]. As expected, diffusion coefficients obtained by rapid acceleration tests for different exposure conditions as well 
at different ages varied and the corresponding variations in diffusion coefficient values were found to be $3.2 \times 10^{-12}$ and $3.1 \times 10^{-12} \mathrm{~m}^{2} / \mathrm{sec}$ for 1 and 2 years of exposure, respectively. Similarly, for the unexposed condition, the diffusion coefficients were $2.7 \times 10^{-12}$ and $3.7 \times 10^{-12} \mathrm{~m}^{2} / \mathrm{sec}$ for 0.5 and 1.3 years, respectively. Empirical models arrived after 1990's clearly established the relationship and the dependency of chloride diffusion values with time and exposure condition, confirming that the chloride diffusion does not solely depend on the characteristics of the material used for the structures. Ultimately, a power function was arrived at and used by several researchers as given by Equation (3) [32-36].

$$
D_{c}=D_{\exp }\left(\frac{t_{\text {exp }}}{t}\right)^{\alpha}
$$

Based on Equation (3), diffusion for 100 years with $\alpha=0.64$ (based on available exposure data) was predicted as 6.6-7.4 $\times 10^{-14} \mathrm{~m}^{2} / \mathrm{s}$. Moreover, the obtained diffusion coefficient, as well as chloride ion ingress, showed highly inconsistent results. The uncertainty in the prediction model was quite large until 1990 and forced the experts to give additional cover depth than predicted.

Evolution of multifaceted methodologies in physicochemical reactions led to the establishment of precise mathematical models replacing simpler error functions deduced and used by Fick's second law. Such a model was given by Mejbro-Poulsen. Arrival at a diffusion coefficient was achieved based on the regression parameter, with the real value being constant in the time interval (0, t). Physical models evolved during 1990's further enriched the evaluation pattern for the detection of chloride ion ingress and service life prediction due to corrosion initiation and propagation [37-39]. "ClinConc" model uses diffusion coefficient obtained from a laboratory test based on non-linear chloride binding and the effect of leaching of alkalis on chloride binding. Chloride binding capacity is not merely a time-dependent process but evolves with respect to mix proportion. Consideration was given for measuring the effect of chloride binding based on the diffusion of alkalis. Moreover, this model considered surface chloride concentration as a constant value. Further analysis was carried out by Tang and Nilson [39], which reduced the time independence of chloride diffusion coefficients by incorporating chloride-binding effect. On updating the previous model used for the calculation of chloride ingress using "ClinCon", it was recommended that chloride-binding capacity of concrete shall be considered as a time-space variant factor. Tang and Nilson [39] arrived at Equation (4) for considering chloride-binding capacity with respect to time.

$$
f\left(t_{c l}\right)=1+a \ln \left(t_{c l}+b\right)
$$

The consistency of the results obtained from experiments and comparison with practical models was found to be inconsistent. This might be attributed to the difference in the time-effect incorporated in both models. In analytical model, the chloride gradient increased due to high surface chloride concentration, which created a larger chloride flux resulting in an increased depth of penetration.

\section{Chloride threshold level}

Sustained level of chloride content at the surface of the steel reinforcement to cause depassivation is called as chloride threshold value (CTV). Chloride threshold value has been represented in three different forms in the literature, as a ratio of chloride ion to hydroxyl ion $\left(\left[\mathrm{Cl}^{-}\right] /\left[\mathrm{OH}^{-}\right]\right)$, as total chloride content and as free chloride content. Since assessment and the prediction of threshold values are interdependent, many researchers have suggested exceedingly elaborated scatter plots for the estimation of CTV based on definite conditions. First assessment of CTL was given by Hausman [40] assuming $\left[\mathrm{Cl}^{-}\right]:\left[\mathrm{OH}^{-}\right]$ratio as 0.6 in a premixed synthetic concrete solution. Moreover, several experimental investigations were carried out during the service life of reinforced concrete (RC) bridges in the United Kingdom and resulted in expression of total chloride content as a percentage of cement in the range of 0.2 to 1.5 . British standards have strictly emphasized and recommended the level of CTV as 0.4 and $0.1 \%$ for RC structures and pre-stressed concrete structures, respectively. Factors such as supplementary cementitious material used, presence of surface cracks, impurities present in concrete, w/c ratio, steel surface condition, type of measurement used and units adopted for measurement significantly influence the chloride threshold values. Despite the influence of these factors, in general, 0.2 to $0.4 \%$ weight of cement is used as a conservative estimate of CTV during the analytical design for the service life of RC structures [41-45]. Chloride content and initiation of corrosion can be identified and measured using several independent measuring techniques, based on distinct measuring principles, such as macro-cell current monitoring technique, half-cell potential technique, AC impedance or polarization technique. Therefore, it is imperative to study the variations in chloride threshold value considering all the influencing parameters for a comprehensive understanding of the same. Moreover, it leads to precise service life prediction of concrete structures against aggressive environments. Influence of different parameters on chloride threshold value is discussed in detail in the following paragraphs.

\subsection{Influence of surface characteristics and metallurgical composition of steel on chloride threshold value}

Experimental and analytical observations compiled from earlier research studies exhibit a varied distribution of chloride threshold values depending on the characteristics of the steel. However, average corrosion rate considered for 
Table 1. Chloride threshold values for reference samples as accounted by different researchers.

\begin{tabular}{|c|c|c|}
\hline Specimen & References & $\begin{array}{l}\text { CTV (\% weight } \\
\text { of cement) }\end{array}$ \\
\hline \multirow{13}{*}{$\begin{array}{l}\text { Ordinary Portland cement } \\
\text { concrete/mortar }\end{array}$} & Richartz [61] & 0.4 \\
\hline & $\begin{array}{c}\text { Gouda and Halaka } \\
{[50]}\end{array}$ & $2.4-3.0$ \\
\hline & $\begin{array}{c}\text { Locke and Siman } \\
{[66]}\end{array}$ & $0.4-0.8$ \\
\hline & $\begin{array}{c}\text { Elsener and Bohni } \\
\text { [82] }\end{array}$ & $0.25-0.5$ \\
\hline & Hope and Ip [81] & $0.1-0.19$ \\
\hline & $\begin{array}{c}\text { Schiessl and Breit } \\
\text { [97] }\end{array}$ & $0.5-1$ \\
\hline & Alonso et al [68] & $1.24-3.08$ \\
\hline & $\begin{array}{c}\text { Zimmermann } \text { et al } \\
{[98]}\end{array}$ & $0.25-1.25$ \\
\hline & $\begin{array}{c}\text { Zimmermann et al } \\
{[98]}\end{array}$ & $0.2-0.4$ \\
\hline & Whiting et al [54] & 0.4 \\
\hline & $\begin{array}{c}\text { Trejo and Pillai } \\
\text { [79] }\end{array}$ & $0.02-0.24$ \\
\hline & $\begin{array}{c}\text { Mohammed and } \\
\text { Hamada [65] }\end{array}$ & $0.4-0.8$ \\
\hline & Manera et al [83] & $1.1-2$ \\
\hline
\end{tabular}

a certain time $\left(\mathrm{I}_{\text {mean }}\right)$, compared with total chloride concentration for the steel with different surface and metallurgical characteristics gave insignificant changes in chloride threshold value [46]. Several researchers have predicted different values of corrosion rate for various types of reinforcements [47]. On the other hand, variations in chloride threshold value were found to be less significant [46]. Further research is needed in light of the contradictory results obtained while considering different types of reinforcements. Equation (5) gives the relationship between average corrosion over a certain period and total chloride concentration for ribbed and smoothed bars [48].

$$
\log I_{\text {mean }}=-1.07+0.76 \log \left(\% \text { total } \mathrm{Cl}^{-}\right)(r=0.80)
$$

Chloride threshold value obtained from the Equation (5) ranged from 1.24 to $3.08 \%$ of total chloride by weight of cement. Similar values were observed by other researchers $[49,50]$ using the same Equation.

Chloride threshold value was investigated for ordinary Portland cement concrete without supplementary cementitious materials by several researchers and the results are listed in table 1.

\subsection{Influence of binder materials on chloride threshold value}

Risk of corrosion of steel reinforcement in RC structures is directly related to the presence of chloride ion concentration in the surrounding concrete. The rate of corrosion increases with the increase in $\left[\mathrm{Cl}^{-}\right] /\left[\mathrm{OH}^{-}\right]$and a critical ratio of 0.61 was proposed in earlier research studies [43].

Pore solution composition of concrete is highly influenced by the type of supplementary material used. Chemical composition and pozzolanic reactivity of supplementary cementitious materials have great influence on inhibiting the concentration of chloride ions because of the pore refining process. Investigation of chloride threshold value (CTV) of steel for concrete with various supplementary cementitious materials was conducted by several researchers and the results are listed in table 2.

3.2a Fly ash: Addition of fly ash has been found to reduce chloride ion concentration in the pore solution because of its higher chloride binding capacity. This can be due to both physical adsorption of chloride because of more gel formation and chemical binding due to the higher content of alumina. Tri-calcium Aluminate $\left(\mathrm{C}_{3} \mathrm{~A}\right)$ and Tetra-calcium Alumino Ferrate have a greater affinity towards holding free chlorides. They bind chlorides to form Friedel's salts and thus reduce the amount of free chlorides readily available for further reaction with pore solution. Nevertheless, increase in $\mathrm{C}_{3} \mathrm{~A}$ also lowers the $\mathrm{pH}$ value of the pore solution [51, 52], making it vulnerable to corrosion. Reduction in permeability of fly ash blended concrete compared to control concrete was observed by many researchers. A case study made in marine environment [53] showed a greater influence of chloride ion inhibition using fly ash as a supplementary cementitious material compared to control specimens. The results showed that an increase in fly ash content decreased the chloride threshold value due to the dilution effect. For instance, $50 \%$ fly ash blended

Table 2. Chloride threshold values for pozzolanic materials.

\begin{tabular}{|c|c|c|}
\hline $\begin{array}{l}\text { Supplementary } \\
\text { cementitious material }\end{array}$ & References & $\begin{array}{l}\text { CTV (\% weight of } \\
\text { cement) }\end{array}$ \\
\hline \multirow[t]{3}{*}{ Fly Ash } & $\begin{array}{c}\text { Schiessl and Breit } \\
{[97,99]}\end{array}$ & $1-1.5$ \\
\hline & Whiting et al [54] & 0.4 \\
\hline & Oh et al [57] & $0.68-0.97$ \\
\hline \multirow[t]{4}{*}{ Silica Fume } & $\begin{array}{l}\text { Hansson and } \\
\text { Sorensen [55] }\end{array}$ & $0.4-1.37$ \\
\hline & Takagi et al [100] & 0.125 \\
\hline & Breit [67] & $0.25-0.75$ \\
\hline & Manera et al [83] & $0.6-1.2$ \\
\hline \multirow[t]{6}{*}{ GGBS } & $\begin{array}{l}\text { Gouda and } \\
\text { Halaka [50] }\end{array}$ & 1 \\
\hline & $\begin{array}{l}\text { Gouda and } \\
\text { Halaka [50] }\end{array}$ & 1.2 \\
\hline & Lambert et al [59] & $1.5-2.5$ \\
\hline & $\begin{array}{c}\text { Schiessl and Breit } \\
\text { [99] }\end{array}$ & $1-1.5$ \\
\hline & Castello et al [58] & 0.23 \\
\hline & Oh et al [57] & 0.45 \\
\hline
\end{tabular}


specimens resulted in a decrease of chloride threshold value by about $70 \%$ [53]. The opposing effects of chloride binding and $\mathrm{pH}$ on chloride threshold value make it difficult to reach at a proper conclusion. However, the chloride threshold value of fly ash blended concrete observed by Whiting et al [54] well agrees with the results from other researchers, for instance, Hansson and Sorensen [55] and Sandberg [17].

3.2b Silica fume: The partial replacement of OPC with silica fume reduces the ability of chloride binding because of the reduction in the aluminate phases, which leads to the higher rate of corrosion in silica fume added concrete, in spite of the higher pore refinement. However, silica blended concrete mixtures have been reported to have lesser chloride binding capacity compared to Portland cement concrete [56]. The alkalinity of pore solution was found to decrease with increased addition of silica fume [52]. From earlier research studies, it was observed that value of chloride threshold for silica fume blended concrete varies from 0.125 to $1.8 \%$ weight of cement, with most of the values coming under $0.4-0.8 \%$. Although pore refinement due to silica fume addition aids in increasing the chloride threshold value, the reduced alkalinity and chloride binding capacity offsets this effect and contributes to an overall reduction in CTV.

3.2c Ground granulated blast furnace slag (GGBFS): The replacement of OPC with blast furnace slag improves the physical and chemical binding properties of the concrete. Oh et al [57] reported insignificant effect due to GGBS addition on chloride threshold value. However, suggested value of chloride threshold for GGBS blended concrete by several researchers varies from 0.23 [58] to 2.5 [59].

Dhir et al [60] conducted extensive studies on the chloride binding capacities of ground granulated slag blended concrete. Unlike silica fume, the chloride binding capacity of the slag blended concrete was found to increase with the level of replacement. It is interesting to note that the chloride ion binding ability increased at higher chloride exposure concentrations. For that reason, higher values of chloride threshold have been reported for GGBFS blended concrete mixtures compared to silica fume blended concrete.

\subsection{Influence of corrosion measurement techniques on chloride threshold value}

Different methods have been proposed for the measurement of CTV. Each measurement technique has its own merits and limitations. Macro-cell type measurement includes ladder system and combination of an anode and a cathode system. Cathode is usually a graphite, titanium or stainless steel and the whole system is embedded above the reinforcement. Inaccurate and improper measurement may arise if the concrete condition is dry and rate of corrosion reading obtained are not direct. One of the most commonly used technique for the measurement of corrosion is Halfcell potential meter $[32,57,61-64]$. The measurement is based on the potential profile plot for reinforcement at different positions. However, this type of measurement has its limitations as potential measurements can be influenced by the amount of carbonation, salt concentration, and moisture level. The rate of corrosion can be directly measured using AC impedance or polarization technique. This can be considered as one of the most accurate forms of the measurement of corrosion. Lack of clarity in the established relationship between corrosion initiation and corrosion rate hinders the establishment of a specific CTV. Generally, $1-2 \mathrm{~mA} / \mathrm{m}^{2}$ is considered as the value at which depassivation is effected [62]. Table 3 shows the range of chloride threshold value obtained by researchers based on various measurement techniques.

3.3a Visual inspection: When steel reinforcement is exposed due to severe spalling, then visual inspection can be a supportive method for determining the chloride threshold value. It can be investigated by the appearance of the rust on the surface of steel. By visual inspection, several researchers have identified the chloride threshold value with the help of simple measurement techniques. Richartz et al [61] had suggested CTV of 0.4, which agrees with the values obtained by Whiting et al [54] in his experimental investigations. Scattered plots were obtained from several research studies ranging from 0.1 to 0.75 .

3.3b Linear polarization resistance (LPR) method: It is one of the widely used electrochemical technique for the measurement of corrosion rate in the steel. In this method, the corrosion rate of the reinforcement bar can be measured in real time. Several researchers used LPR method for the measurement of the chloride threshold value for different type of reinforcements with dissimilar surface characteristics and intrinsic concrete properties. Considerable variations in the results were obtained by different researchers.

Chloride threshold value obtained by Mohammed and Hamada [65] for mild steel is identical with CTV obtained by Locke and Siman [66]. However, the type of reinforcement used by Locke and Siman [66] was ribbed steel. Overall chloride threshold values given by many researchers measured using LPR method varies from 0.4 to 3.08. However, conclusive findings cannot be obtained for specific kind of variations by incorporating different factors involved in the prediction of CTV.

3.3c Macrocell current method: Calibration of chloride threshold value using macrocell current method gives the spread and range of CTV from 0.2 to 1.5. Nevertheless, specifics for the corrosion measurement using macrocell obtained from earlier research studies were limited, as the 
Table 3. Chloride threshold values (CTV) based on measurement method.

\begin{tabular}{|c|c|c|}
\hline $\begin{array}{l}\text { Corrosion measurement } \\
\text { type }\end{array}$ & References & $\begin{array}{l}\text { CTV (\% weight } \\
\text { of cement) }\end{array}$ \\
\hline \multirow[t]{5}{*}{ Visual inspection } & Richartz [61] & 0.4 \\
\hline & $\begin{array}{c}\text { Elsner and Bohni } \\
{[82]}\end{array}$ & $0.25-0.5$ \\
\hline & Hope and Ip [81] & $0.1-0.19$ \\
\hline & Castello et al [58] & 0.15 \\
\hline & $\begin{array}{l}\text { Nygaard and } \\
\text { Geiker [101] }\end{array}$ & $0.52-0.74$ \\
\hline \multirow[t]{9}{*}{$\begin{array}{l}\text { Linear polarization } \\
\text { resistance (LPR) }\end{array}$} & $\begin{array}{c}\text { Locke and Siman } \\
\text { [66] }\end{array}$ & $0.4-0.8$ \\
\hline & Hope and Ip [81] & $0.1-0.19$ \\
\hline & Lambart et al [59] & $1.5-2.5$ \\
\hline & Alonso et al [68] & $1.24-3.08$ \\
\hline & Castello et al [58] & 0.23 \\
\hline & Whiting et al [54] & 0.4 \\
\hline & $\begin{array}{l}\text { Nygaard and } \\
\text { Geiker [101] }\end{array}$ & $0.52-0.74$ \\
\hline & $\begin{array}{c}\text { Mohammed and } \\
\text { Hamada [65] }\end{array}$ & $0.4-0.8$ \\
\hline & Manera et al [83] & $1.1-2$ \\
\hline \multirow[t]{6}{*}{ Macro-cell current } & $\begin{array}{l}\text { Schiessel and } \\
\text { Raupach [99] }\end{array}$ & 0.5 \\
\hline & $\begin{array}{l}\text { Schiessel and } \\
\text { Raupach [99] }\end{array}$ & $0.5-2$ \\
\hline & $\begin{array}{c}\text { Schiessl and Breit } \\
\text { [97] }\end{array}$ & $0.5-1$ \\
\hline & $\begin{array}{c}\text { Schiessl and Breit } \\
\text { [97] }\end{array}$ & $1-1.5$ \\
\hline & $\begin{array}{c}\text { Zimeermann } \text { et al } \\
{[98]}\end{array}$ & $0.25-1.25$ \\
\hline & $\begin{array}{c}\text { Zimeermann } \text { et al } \\
{[98]}\end{array}$ & $0.2-0.4$ \\
\hline
\end{tabular}

measurements made using this technique should need reference with respect to concrete moisture condition.

\subsection{Influence of type of reinforcement on chloride threshold value}

3.4a Mild steel: Several researchers performed diverse studies and suggested the chloride threshold value for mild steel based on their observations. Study conducted by Richartz [61] proposed $0.4 \%$ weight of cement as CTV, which well agreed with the results from other studies by Hansson and Sorensen [55], Breit [67] and Mohammed and Hamada [65].

However, there is a striking contrast in CTV suggested by Gouda and Halaka [50] and Mohammed and Hamada [65]. After organizing all the results of CTV for mild steel, value is found to vary between 0.02 to $3.08 \%$ by weight of cement. As the given values are exceptionally dispersed, it is difficult to suggest a particular value for chloride threshold from earlier research studies as it depends on many more parameters as mentioned earlier. However, in absence of further studies incorporating other influencing parameters, CTV for mild steel from the existing literature can be considered to fall in the range of $0.68-0.7$.

3.4b Ribbed steel: Based on investigations performed by several researchers considering different influential factors, various chloride threshold values were obtained. Alonso et al [68] reported that ribbed steel bars are highly susceptible to corrosion compared to mild steel as the ribs on the surface of steel can accommodate voids and proposed the chloride threshold value range between 1.24 and $3.08 \%$ weight of cement.

The same authors later contradict their previous results by suggesting $0.73 \%$ weight of cement as chloride threshold value for ribbed steel [69]. Study performed by Locke and Siman [66] and Mohammed and Hamada [65] have suggested the same value $0.4-0.8 \%$ by weight of cement. However, values suggested by other researchers are exceptionally scattered. From the available data, CTV for ribbed steel can be considered nearly equal to $0.6 \%$ weight of cement as it satisfies most of the listed CTV ranges in the existing literature. From the past research records, overall value of chloride threshold value of ribbed steel was found to vary from 0.2 to 3.085 by weight of cement as given in table 5 .

3.4c Epoxy coated steel: Several studies have been performed by many researchers on epoxy-coated steel to investigate the chloride threshold value. Some of the researchers proposed the value based on the percentage of damage on the epoxy coating and few researchers projected the specific value for epoxy coated steel reinforcement. List of CTV limits given by various researchers are given in table 6. Based on the percentage of damage on epoxy coating, Ann and Song [70] and Deb [71] reported the same value of chloride threshold, whereas Basham [72] suggested the chloride threshold value same as that of black steel when the percentage of damage to coating is $0.5 \%$.

Most of the proposed CTV values fall in the range of 0.62 to $1.24 \%$ by weight of cement, while McKeel [73], Phares et al [63] and Lau [74] suggested values which are far out of the range. Thus, the CTV value for epoxy steel can be considered as $1.15 \%$ weight of cement in the absence of further research data, as it satisfies most of the value ranges suggested by various researchers.

3.4d Pre-stressing test: It is interesting to note that when pre-stressing steel is highly stressed, it is less tolerant to corrosive environments compared to normal reinforcement [75].

Thus, the chloride threshold value of pre-stressing steel is much lesser than that of normal reinforcement, which is reported in many of the international standards. 
However, a number of experimental investigations performed by previous researchers showed different CTV values than that proposed in the current standards. Alonso et al [76] had specified 1.2-2\% weight of chloride as chloride threshold value for pre-stressing steel. Observations from Pfeifer et al [77], Lee [75] and Azuma et al [78] are found to be in line with the results of Alonso et al [76]. However, there is still ambiguity in the value of chloride threshold for pre-stressing steel. Summary of chloride threshold values used by various researchers in their study for pre-stressing steel is given in table 7 .

\subsection{Other influencing parameters on chloride threshold value}

In addition to the above mentioned factors, a number of other external parameters were found to govern the Chloride Threshold Value. Typically, external parameters include environmental intermittency, availability of oxygen and moisture content at rebar level, temperature, relative humidity, entry of acidic gases, chloride ion ingression, resistivity, etc. It is important to note that various analytical software for predicting service life considers chloride threshold value solely as a property of the steel used and does not take any of the other parameters in to consideration, resulting in erroneous calculation of chloride threshold value. For example, Life-365 is a commonly used analytical software for service life prediction and life cycle cost assessment. In the analysis, it assumes the same value of chloride threshold value for black steel and epoxy steel, which is not correct. Although Life-365 gives appropriate results when used for service life prediction, assumption of constant CTV for all reinforcements leads to improper estimation of corrosion initiation period. For this reason, the chloride threshold value should be reconsidered prior to execution of the analysis for different type of steel reinforcements.

3.5a Pore solution $\mathrm{pH}$ : The $\mathrm{pH}$ value of the pore solution is one of the most important parameters that governs the passivation of the steel protecting it from risk of corrosion. The steel remains passive above a $\mathrm{pH}$ value of 13 . However, as the chloride content in the pore solution reaches a limiting value, the depassivation process begins. At a $\mathrm{pH}$ value less than 11.5 , corrosion is initiated. Percentage of chloride requirement to initiate the corrosion fluctuates highly as the $\mathrm{pH}$ level of the pore solution drops down [50]. Nearly, for each decrease in the $\mathrm{pH}$ level by 0.5 , CTV reduces up to $69 \%$. As pH level further drops below 11, requirement of chloride for corrosion initiation further drops to about $0.002 \mathrm{~g} / \mathrm{L}[50]$.

3.5b Oxygen and moisture content level at rebar: Moisture and oxygen act as essential feeders for corrosion. Rust $\left(\mathrm{Fe}(\mathrm{OH})_{2}\right)$ is formed as a result of the increase in the level of $\mathrm{OH}^{-}$ions. The available moisture content at the rebar level acts as the electrolyte medium required for the corrosion process. Cathodic reaction intensifies in by the presence of oxygen. Even at the stage of depassivation, without an adequate amount of oxygen, the progress of corrosion will halt, as there will not be enough oxygen for an effective cathodic polarization.

3.5c Temperature, relative humidity $(R H)$ and resistivity: Temperature has an extremely high influence on the chloride threshold value (CTV). Five-fold reduction in chloride threshold value (CTV) was observed on increasing the temperature from $20^{\circ} \mathrm{C}$ to $70^{\circ} \mathrm{C}$. Moreover, reduction in pore solution $\mathrm{pH}$ and percentage of bound chloride was also observed with increased temperature [47]. Hussain et al enumerated the effect of resistivity on CTV and reported that the chloride threshold value (CTV) increased from 0.44 to $2.32 \%$ with a corresponding increase of resistivity from 2 to $100 \mathrm{k} \Omega-\mathrm{cm}$ [47]. Moreover, Relative Humidity (RH) is found to influence the surface chloride concentration; one of the most important factors in depassivation of steel. However, it needs to be remembered that variation of chemical composition of reinforcement also influence the chloride threshold value required for corrosion. CTV varies from 0.04 to $0.09 \%$ for mild steel with $0.18-0.55 \%$ of Nickel and Chromium content, respectively. Similarly, for steel with 0.82 and $1.91 \%$ of Nickel and Chromium, Chloride Threshold Value (CTV) varies from 8.64 to $10.8 \%$ and 10 to $18 \%$, respectively $[79,80]$.

It is apparent from tables 4, 5, 6, 7 that the chloride threshold value across various studies vary even if the reinforcement used in the studies are the same. The critical chloride concentration depends on a number of environmental factors not all of which can be identical in research studies. Therefore, treating CTV as dependent on a single parameter across various studies will lead to misleading interpretations.

The different governing factors on estimation of chloride threshold value as well as its measurement are summarized together in table 8 . Based on the inconsistencies in the

Table 4. Chloride threshold values based for mild steel reported in the literature.

\begin{tabular}{lc}
\hline References & CTV (\% weight of cement) \\
\hline Richartz [61] & 0.4 \\
Gouda and Halaka [50] & 3 \\
Hansson and Sorensen [55] & $0.4-1.37$ \\
Lambart et al [59] & $1.5-2.5$ \\
Breit [67] & $0.25-0.75$ \\
Alonso et al [68] & $1.24-3.08$ \\
Trejo and Pillai [80] & $0.02-0.24$ \\
Oh et al [57] & 0.45 \\
Nygaard and Geiker [101] & $0.52-0.75$ \\
Mohammed and Hamada [65] & $0.4-0.8$ \\
Manera et al [83] & $1.1-2$ \\
Manera et al [83] & $0.6-1.2$
\end{tabular}


Table 5. Chloride threshold values based for ribbed steel reported in the literature.

\begin{tabular}{lc}
\hline References & CTV (\% weight of cement) \\
\hline Clear [102] & 0.2 \\
Locke and Siman [66] & $0.4-0.8$ \\
Schiessl and Breit [97] & $0.5-1$ \\
Thomas [53] & $0.2-0.65$ \\
Alonso et al [68] & $1.24-3.08$ \\
Alonso et al [69] & 0.73 \\
Castello et al [58] & 0.23 \\
Nygaard and Geiker [101] & $0.52-0.74$ \\
Mohammed and Hamada [65] & $0.4-0.8$ \\
Manera et al [83] & $1.1-2$ \\
Manera et al [83] & $0.6-1.2$ \\
\hline
\end{tabular}

Table 6. Chloride threshold values based for epoxy coated steel reported in the literature.

\begin{tabular}{|c|c|}
\hline References & CTV (\% weight of cement) \\
\hline Sagues et al [64] & $0.2-0.62$ \\
\hline $\begin{array}{l}\text { Sohanghpurwala et al } \\
\text { [103] }\end{array}$ & 0.62 \\
\hline McKeel [73] & 0.2 \\
\hline Basham [72] & $\begin{array}{c}\text { Damage level } 0.5 \% \text {-same as black steel } \\
\text { Damage level } 0.004 \% \text {-very high }\end{array}$ \\
\hline Fanous and $\mathrm{Wu}[104]$ & $0.62-1.24$ \\
\hline Darwin et al [105] & $0.2-0.62$ \\
\hline Trejo and Pillai $[79,80]$ & $\begin{array}{c}2.0-2.6(\% \text { weight of mortar }) \\
\text { w/c }=0.45 \\
0.4-2.1 \text { (\% weight of mortar }) ; \\
\text { w/c }=0.55\end{array}$ \\
\hline Phares et al [63] & 0.29 \\
\hline Ann and Song [70] & $\begin{array}{c}1 \% \text { damage }-2 \% \\
2 \% \text { damage- } 0.4 \% \text { (by weight of } \\
\text { cement) }\end{array}$ \\
\hline Lau [74] & 0.44 \\
\hline $\begin{array}{l}\text { Darwin et al [105], } \\
\text { O'Reilly et al [106] }\end{array}$ & 1.24 \\
\hline Deb [71] & $\begin{array}{c}1 \% \text { damage to coating, } 2 \% \text { by weight } \\
\text { of cement, } 2 \% \text { damage, CTL was } \\
\text { below } 0.4 \% \text {. }\end{array}$ \\
\hline Lawler et al [107] & 1.15 \\
\hline
\end{tabular}

measurement of CTV values observed from the earlier research studies, a recommendation is given in figure 1 as a framework for the measurement of CTV values by accounting for different influential parameters.

\section{Variation in chloride threshold value in the published literature}

From tables 1 to 7 , it can be seen that the reported chloride threshold values across various investigations have not attained consensus. The least values of CTV for studies
Table 7. Chloride Threshold Values limits as accounted by different researches for pre-stressing steel.

\begin{tabular}{lc}
\hline References & $\begin{array}{c}\text { Prescribed CTV (\% } \\
\text { weight of cement) }\end{array}$ \\
\hline AASHTO LRFD & 0.08 \\
Specifications for Grouting of Post- & 0.08 \\
$\quad$ Tensioned Structures, PTI M55.01- & \\
03 & \\
Guide to Durable Concrete & 0.08 \\
$\quad$ ACI201.2R-08 & \\
ACI 222R-01 & 0.08 \\
& 0.06 \\
ACI 318M-11 & 0.06 \\
EN 447 & 0.10 \\
Canadian Standards Association CSA- & 0.06 \\
$\quad$ A23.1-09 & \\
New Zealand RMC Association, Inc & 0.14 \\
Japan Prestressed Concrete & 0.023 \\
$\quad$ Engineering Association & \\
HongKong Buildings Department & 0.10 \\
Stark [108] & 0.17 \\
Pfeiffer [109] & 1.4 \\
Lee [75] & $1.2-1.4 \%$ \\
Wang et al [110] & 0.08 \\
Azuma et al [78] & 1.2 \\
Alonso et al [111] & 1.2 to $2 \%$. \\
Trejo et al [112] & 0.018 \\
\hline
\end{tabular}

involving ordinary Portland cement were reported by Trejo and Pillai [79], Hope and Ip [81], and Elsener and Bohni [82], while Alonso et al [68] reported higher values in the range of 1.24-3.08. Richartz [61] had suggested $0.4 \%$ weight of cement, which concurs more or less with the values suggested by other researchers.

The higher values for CTV reported by Alonso et al might be attributed to the use of experimental specimens in which reinforcement was embedded in mortar with Portland cement containing high $\mathrm{C}_{3} \mathrm{~A}$ content [68]. Tricalcium Aluminate binds with chloride, thus converting the free chlorides in the pore solution to bound chlorides, which cannot take part in the depassivation process. Similarly, Manera et al [83] described two different CTVs a range of 1.1-2\% was reported for OPC concrete and a range of $0.6-1.2 \%$ in the case of silica fume blended concrete. Although further replacement of silica fume refines pores, it reduces alkalinity of the pore solution, resulting in a comparative reduction of binding ability of chloride by the formation of Friedel's salt, which is highly soluble at lower $\mathrm{pH}$ [52]. Due to these opposing effects of binder materials on $\mathrm{pH}$ and pore refinement properties, it is difficult to achieve a proper linear relationship between the level of replacement of various binder materials and their chloride threshold values. Further research in this regard is needed to obtain a range of CTV for a fixed set of parameters such that they may be used in service life predictions. 
Table 8. Chloride threshold value based on different parameters.

\begin{tabular}{|c|c|c|c|c|c|}
\hline \multirow[b]{2}{*}{ Study } & \multicolumn{4}{|c|}{ Parameter } & \multirow[b]{2}{*}{ CTV (\% weight of cement) } \\
\hline & $\begin{array}{c}\text { Steel } \\
\text { condition }\end{array}$ & Composition of binder & $\begin{array}{l}\text { Water/ } \\
\text { binder (w/ } \\
\text { b) ratio }\end{array}$ & $\begin{array}{c}\text { Corrosion } \\
\text { measurement type }\end{array}$ & \\
\hline Hausmann [40] & $\begin{array}{r}\text { Cleaned, } \\
\text { smooth }\end{array}$ & - & - & $\begin{array}{c}\text { Potential, visual } \\
\text { inspection }\end{array}$ & 0.6 \\
\hline Richartz [61] & Smooth & $100 \%$ OPC & 0.45 & Visual inspection & 0.4 \\
\hline $\begin{array}{l}\text { Gouda and } \\
\text { Halaka [50] }\end{array}$ & Smooth & $100 \%$ OPC & 0.6 & $\begin{array}{c}\text { Anodic polarization, } \\
\text { potential }\end{array}$ & 3.0 \\
\hline $\begin{array}{l}\text { Gouda and } \\
\text { Halaka [50] }\end{array}$ & Smooth & $35 \%$ GGBS $+65 \%$ OPC & 0.6 & $\begin{array}{c}\text { Anodic polarization, } \\
\text { potential }\end{array}$ & 1.0 \\
\hline $\begin{array}{l}\text { Gouda and } \\
\text { Halaka [50] }\end{array}$ & Smooth & $100 \%$ OPC & - & $\begin{array}{c}\text { Anodic polarization, } \\
\text { potential }\end{array}$ & 2.4 \\
\hline $\begin{array}{l}\text { Gouda and } \\
\text { Halaka [50] }\end{array}$ & Smooth & $35 \%$ GGBS $+65 \%$ OPC & - & $\begin{array}{c}\text { Anodic polarization, } \\
\text { potential }\end{array}$ & 1.2 \\
\hline $\begin{array}{l}\text { Stratfull et al } \\
\quad[113]\end{array}$ & - & Various & - & Potential & $0.17-1.4$ \\
\hline Clear [102] & Ribbed & - & - & - & 0.2 \\
\hline $\begin{array}{l}\text { Locke and Siman } \\
\text { [66] }\end{array}$ & $\begin{array}{r}\text { Cleaned, } \\
\text { ribbed }\end{array}$ & $100 \%$ OPC & 0.4 & LPR & $0.4-0.8$ \\
\hline $\begin{array}{l}\text { Lambert et al } \\
\text { [59] }\end{array}$ & - & - & - & - & $0.2-1.5$ \\
\hline Stark [108] & $\begin{array}{l}\text { 7—wire } \\
\text { strand }\end{array}$ & - & - & - & $\begin{array}{c}0.11-0.17 \text { (water soluble } \\
\text { chloride) }\end{array}$ \\
\hline Pfeifer et al [77] & - & - & - & - & 0.25 \\
\hline Lukas [114] & - & - & - & - & $1.8-2.2$ \\
\hline $\begin{array}{l}\text { Elsner and Bohni } \\
\text { [82] }\end{array}$ & Sand blasted & $100 \%$ OPC & 0.5 & $\begin{array}{c}\text { EIS, visual } \\
\text { inspection, weight } \\
\text { loss }\end{array}$ & $0.25-0.5$ \\
\hline Pfeifer [109] & $\begin{array}{l}\text { 7-wire } \\
\text { strand }\end{array}$ & - & - & - & $1.2-1.4$ \\
\hline Hope and Ip [81] & Polished & $100 \%$ OPC & 0.45 & $\begin{array}{l}\text { LPR, EIS, visual } \\
\text { inspection, weight } \\
\text { loss }\end{array}$ & $0.1-0.19$ \\
\hline Hope and Ip [81] & Polished & $100 \%$ OPC & 0.45 & $\begin{array}{l}\text { LPR, EIS, visual } \\
\text { inspection, weight } \\
\text { loss }\end{array}$ & $0.1-0.19$ \\
\hline $\begin{array}{l}\text { Goni and } \\
\quad \text { Andrade [115] }\end{array}$ & Cleaned & & - & LPR, potential & $0.15-0.30$ \\
\hline $\begin{array}{l}\text { Hansson and } \\
\text { Sorensen [55] }\end{array}$ & $\begin{array}{l}\text { Cleaned, } \\
\text { smooth }\end{array}$ & $\begin{array}{c}\text { OPC, FA, SRPC, SF, } \\
\text { RHPC }\end{array}$ & $0.4-0.6$ & $\begin{array}{c}\text { Current between WE } \\
\text { and Passive } \\
\text { external CE }\end{array}$ & $0.4-1.37$ \\
\hline $\begin{array}{l}\text { Schiessel and } \\
\text { Raupach [99] }\end{array}$ & - & - & $0.4-0.6$ & Macrocell current & 0.5 \\
\hline $\begin{array}{l}\text { Schiessel and } \\
\text { Raupach [99] }\end{array}$ & - & - & $0.4-0.6$ & Macrocell current & $0.5-2.0$ \\
\hline $\begin{array}{l}\text { Thomas et al } \\
\text { [116] }\end{array}$ & - & - & & & 0.5 \\
\hline $\begin{array}{l}\text { Lambart et al } \\
\text { [59] }\end{array}$ & $\begin{array}{l}\text { Cleaned, } \\
\text { smooth }\end{array}$ & OPC, SRPC & 0.5 & LPR, potential & $1.5-2.5$ \\
\hline $\begin{array}{l}\text { Takagi et al } \\
\text { [100] }\end{array}$ & - & $70 \% \mathrm{OPC}+30 \% \mathrm{SF}$ & - & Half cell potential & 0.125 \\
\hline $\begin{array}{l}\text { Hussain et al } \\
\text { [47] }\end{array}$ & - & $\begin{aligned}(\mathrm{C} 3 \mathrm{~A} \text { content } & =2.43 \%) \\
(\mathrm{C} 3 \mathrm{~A} \text { content } & =7.59 \%) \\
(\mathrm{C} 3 \mathrm{~A} \text { content } & =14.0 \%)\end{aligned}$ & & & $\begin{array}{c}0.35(\mathrm{C} 3 \mathrm{~A} \text { content }=2.43 \%) \\
0.62(\mathrm{C} 3 \mathrm{~A} \text { content }=7.59 \%) \\
1.0(\mathrm{C} 3 \mathrm{~A} \text { content }=14.0 \%)\end{array}$ \\
\hline $\begin{array}{l}\text { Mammoliti et al } \\
\text { [48] }\end{array}$ & Ground & - & - & Anodic polarization & 0.5 \\
\hline
\end{tabular}


Table 8 continued

\begin{tabular}{|c|c|c|c|c|c|}
\hline \multirow[b]{2}{*}{ Study } & \multicolumn{4}{|c|}{ Parameter } & \multirow[b]{2}{*}{ CTV (\% weight of cement) } \\
\hline & $\begin{array}{c}\text { Steel } \\
\text { condition }\end{array}$ & Composition of binder & $\begin{array}{l}\text { Water/ } \\
\text { binder (w/ } \\
\text { b) ratio }\end{array}$ & $\begin{array}{c}\text { Corrosion } \\
\text { measurement type }\end{array}$ & \\
\hline $\begin{array}{l}\text { Mammoliti et al } \\
\text { [48] }\end{array}$ & Ribbed & - & - & $\begin{array}{c}\text { Anodic } \\
\text { POLARIZATION }\end{array}$ & 1 \\
\hline $\begin{array}{l}\text { Mammoliti et al } \\
\text { [48] }\end{array}$ & Polished & - & - & Anodic polarization & 1.5 \\
\hline $\begin{array}{r}\text { Schiessl and } \\
\text { Breit [97] }\end{array}$ & Ribbed & $100 \%$ OPC & $05-0.7$ & Macrocell current & $0.5-1.0$ \\
\hline $\begin{array}{r}\text { Schiessl and } \\
\text { Breit [97] }\end{array}$ & Ribbed & OPC With GGBS or FA & $0.5-0.7$ & Macrocell current & $1.0-1.5$ \\
\hline Thomas [53] & Ribbed & OPC with 15 to $50 \%$ FA & $0.32-0.68$ & Weight loss & $0.2-0.65$ \\
\hline $\begin{array}{l}\text { Sohanghpurwala } \\
\text { et al [103] }\end{array}$ & - & - & - & - & $0.75 \mathrm{Kg} / \mathrm{m}^{3}$ of concrete \\
\hline Elsner et al [82] & - & $100 \%$ OPC & 0.75 & Potential & \\
\hline Breit [67] & Cleaned & - & - & $\begin{array}{l}\text { Potentiostatic } \\
\text { testing, visual } \\
\text { inspection }\end{array}$ & \\
\hline Breit [67] & Smooth & $\begin{array}{c}100 \% \text { OPC, } 100 \% \text { SRPC } \\
\text { and OPC with SF, FA or } \\
\text { GGBS }\end{array}$ & $0.5-0.6$ & $\begin{array}{l}\text { Potentiostatic } \\
\text { testing, visual } \\
\text { inspection }\end{array}$ & $0.25-0.75$ \\
\hline Alonso et al [68] & $\begin{array}{l}\text { Ribbed and } \\
\text { smooth }\end{array}$ & $100 \%$ OPCs & 0.5 & LPR, potential & $1.24-3.08$ \\
\hline $\begin{array}{l}\text { Zimeermann } \\
\text { et al }[98]\end{array}$ & $\begin{array}{c}\text { Sandblasted, } \\
\text { clean }\end{array}$ & - & - & $\begin{array}{c}\text { Potential, Macrocell } \\
\text { current }\end{array}$ & \\
\hline $\begin{array}{l}\text { Zimeermann } \\
\text { et al [98] }\end{array}$ & $\begin{array}{c}\text { Sandblasted, } \\
\text { clean }\end{array}$ & $100 \%$ OPC & 0.6 & $\begin{array}{c}\text { Potential, Macrocell } \\
\text { current }\end{array}$ & $0.25-1.25$ \\
\hline $\begin{array}{l}\text { Zimeermann } \\
\text { et al }[98]\end{array}$ & - & $100 \%$ OPC & - & Macrocell current & $0.2-0.4$ \\
\hline Sagues et al [64] & $\begin{array}{l}\text { Sandblasted, } \\
\text { pre-rusted }\end{array}$ & $100 \%$ OPC & - & Potential, EIS & \\
\hline Alonso et al [69] & $\begin{array}{l}\text { Ribbed, } \\
\text { millscaled }\end{array}$ & - & 0.5 & Potentiostatic control & 0.73 \\
\hline $\begin{array}{l}\text { Castello et al } \\
\text { [58] }\end{array}$ & Ribbed & $100 \%$ SRPC & 0.37 & LPR, potential & 0.23 \\
\hline $\begin{array}{l}\text { Castello et al } \\
\text { [58] }\end{array}$ & $\begin{array}{l}\text { Cleaned } \\
\text { (Acetone) }\end{array}$ & $100 \%$ SRPC & 0.37 & $\begin{array}{l}\text { Potentiostatic } \\
\text { testing, visual } \\
\text { inspection }\end{array}$ & 0.15 \\
\hline $\begin{array}{l}\text { Whiting et al } \\
\text { [54] }\end{array}$ & $\begin{array}{l}\text { Cleaned } \\
\text { (Acetone) }\end{array}$ & $100 \%$ OPC (7-12\% C3A) & $0.4-0.6$ & $\begin{array}{l}\text { Potentiostatic } \\
\text { testing, visual } \\
\text { inspection }\end{array}$ & 0.4 \\
\hline $\begin{array}{l}\text { Whiting et al } \\
\text { [54] }\end{array}$ & Cleaned & $\begin{array}{c}75 \% \text { OPC }+25 \% \mathrm{FA} \\
(\text { Classs } \mathrm{C} \text { and } \mathrm{F})\end{array}$ & $0.4-0.6$ & LPR & 0.4 \\
\hline $\begin{array}{l}\text { Trejo and Pillai } \\
\text { [79] }\end{array}$ & Smooth & $100 \%$ OPC & 0.5 & Potential & $0.02-0.24$ \\
\hline Trejo et al [112] & $\begin{array}{l}\text { Mill scaled } \\
\text { bar }\end{array}$ & - & - & - & $0.05-0.15$ \\
\hline Oh et al [57] & Smooth & $\begin{array}{c}\text { OPC with } 15 \text { to } 30 \% \text { FA } \\
\text { and } 30 \% \text { GGBS }\end{array}$ & $0.35-0.55$ & Potential & $0.68-0.97$ \\
\hline Oh et al [57] & Smooth & SRPC & $0.35-0.55$ & Potentiostatic control & 0.45 \\
\hline Sagues et al [64] & 7-wire stand & - & - & - & $\begin{array}{c}0.08 \text { by a conversion factor of } \\
1.493 \text { from grout weight to } \\
\text { cement weight }\end{array}$ \\
\hline $\begin{array}{l}\text { Nygaard and } \\
\text { Geiker [101] }\end{array}$ & $\begin{array}{l}\text { Smooth, } \\
\text { ribbed and } \\
\text { sandblast }\end{array}$ & $100 \%$ OPC & 0.45 & $\begin{array}{l}\text { LPR, potential, } \\
\text { visual inspection }\end{array}$ & $0.52-0.74$ \\
\hline
\end{tabular}


Table 8 continued

\begin{tabular}{|c|c|c|c|c|c|}
\hline \multirow[b]{2}{*}{ Study } & \multicolumn{4}{|c|}{ Parameter } & \multirow[b]{2}{*}{ CTV (\% weight of cement) } \\
\hline & $\begin{array}{c}\text { Steel } \\
\text { condition }\end{array}$ & Composition of binder & $\begin{array}{l}\text { Water/ } \\
\text { binder (w/ } \\
\text { b) ratio }\end{array}$ & $\begin{array}{l}\text { Corrosion } \\
\text { measurement type }\end{array}$ & \\
\hline Phares et al [63] & - & - & - & - & $0.63 \mathrm{Kg} / \mathrm{m}^{3}$ of concrete \\
\hline Azuma et al [78] & $\begin{array}{r}\text { 7-wire } \\
\text { strand }\end{array}$ & - & - & - & - \\
\hline $\begin{array}{c}\text { Mohammed and } \\
\text { Hamada [65] }\end{array}$ & $\begin{array}{l}\text { Smooth, } \\
\text { ribbed and } \\
\text { sandblast }\end{array}$ & $100 \%$ OPC & 0.5 & LPR, potential & \\
\hline Manera et al [83] & $\begin{array}{l}\text { Smooth, } \\
\text { ribbed and } \\
\text { sandblast }\end{array}$ & $100 \%$ OPC & 0.6 & LPR, potential & $1.1-2.0$ \\
\hline Manera et al [83] & $\begin{array}{l}\text { Smooth, } \\
\text { ribbed and } \\
\text { sandblast }\end{array}$ & $90 \% \mathrm{OPC}+10 \% \mathrm{SF}$ & 0.6 & LPR, potential & $0.6-1.2$ \\
\hline $\begin{array}{l}\text { Darwin et al } \\
\quad[105]\end{array}$ & - & - & - & - & $0.967 \mathrm{Kg} / \mathrm{m}^{3}$ of concrete \\
\hline Trejo et al [112] & $\begin{array}{r}\text { 7-wire } \\
\text { strand }\end{array}$ & - & - & - & $0.006-0.018$ \\
\hline $\begin{array}{l}\text { O'Reilly et al } \\
\text { [106] }\end{array}$ & - & - & - & - & $0.967 \mathrm{Kg} / \mathrm{m}^{3}$ of concrete \\
\hline
\end{tabular}

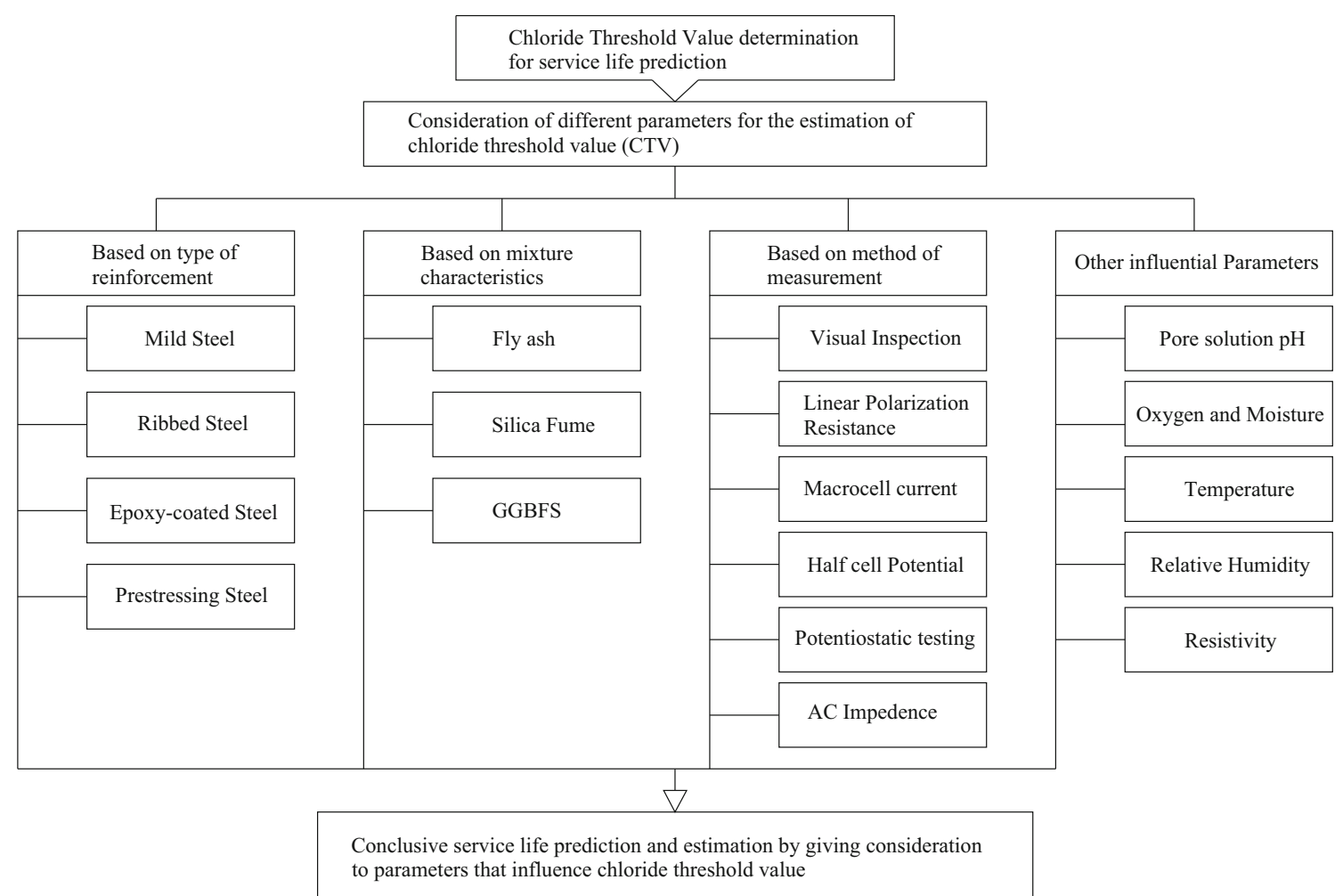

Figure 1. Flowchart for estimating and expressing a conclusive chloride threshold value (CTV) or range.

Moreover, researchers reported that the method of testing is a vital influencing factor for variation of CTV. The testing methods adopted to determine CTV are not consistent in the reported literature. For instance, some studies use titration methods to find out the concentration of chloride content after testing while others have reported the 
usage of X-ray fluorescence (XRF) spectroscopy. The differences in the location of sampling could also have contributed to the variation in values observed by Hanson and Sorenson [55]. While the sample used for titration was taken approximately $2 \mathrm{~mm}$ away from the reinforcement, sample for XRF analysis was directly scrapped adjacent to steel [55].

As for concrete/mortars embedded with ribbed steel, major difference in values was observed by Alonso et al $[68,69]$ and Manera et al [83]. Since the rebar type is kept constant, the main influential factor behind this difference on CTV may be the method of introduction of chloride and the usage of high $\mathrm{C}_{3} \mathrm{~A}$ cement. Studies in which chloride was admixed in the fresh state of concrete/ mortar showed lesser CTV than studies in which chloride penetration mechanism was diffusion [69] in hardened concrete. However, for similar rebar composition, the surface characteristics (smooth/ribbed) did not much influence the critical chloride threshold value [68].

It is interesting to note that although key parameters are kept constant in various studies, there is significant variation in the determined CTV. Even within a single study where the external potential was employed to accelerate the corrosion process and the type of cement remained same, slight scatter in CTV has been observed [68]. Since a wide range of factors (as listed in the anteceding sections) influence the critical chloride concentration that initiates corrosion, a blind one-for-all approach will result in wildly misleading service life predictions. Therefore, instead of a single value, a range of values may be given for CTV within which most of the experimental values fall for the most likely experimental conditions. Since environmental factors (relative humidity, temperature, wind velocities, etc.) play a major role in corrosion initiation, instead of developing a framework for a universally acceptable CTV based on material characteristics, a need-based local approach that considers the immediate surroundings of the structure to be constructed is necessary.

\section{Specifications related to chloride: Perspectives from Indian and international standards}

\subsection{Aci 318-2011}

ACI 318-11 [84] is the standard for Building Requirements for Structural Concrete. It includes the provisions concerning minimum requirement for materials, design and construction practices. Chapter 4 of the standard deals with the durability aspects, defines the exposure conditions for concrete based on severity, and provides requirement for water cement ratio and strength for each exposure condition. In addition, it provides requirements corresponding to air content, maximum water soluble chloride content in concrete and cementitious material type based on each exposure class. Table 8 classifies the chloride exposure classes and its minimum requirement as per ACI 318-11 [84]. Chloride ion in the concrete comes from different concrete ingredients including water, aggregate, mineral admixture and cementitious material. Moreover, ACI 201.2R [85] specifies guidelines to achieve durable concrete by providing an upper limit to the available chloride in the system based on the exposure condition. According to guidelines, chloride content of the binder is typically very low when fly ash and silica fume are used as admixtures, whereas for slag it is significant if quenched with seawater. It specifies the chloride content limit for aggregate and water, which is used to prepare the mix. It relates water cement ratio and concrete cover provided for sea or brackish water. Water cement ratio is specified to be not more than 0.4. In extreme cases, it may go up to a maximum of 0.45 , but thickness of the cover should be increased simultaneously. Additionally, it highlights the protective system against the corrosion, which is to be adopted based on different exposure conditions.

\subsection{As 3600-2001}

AS 3600-2001 [86] is an Australian standard for Concrete Structures, describing the minimum requirements for design and construction of plain and reinforced concrete structure. It defines the durability parameters but does not cover the requirement provision for materials constituents and proportions. Based on geographical location, it classifies the exposure conditions from $\mathrm{A}$ to $\mathrm{C}$; where $\mathrm{A}$ is the mildest condition, $\mathrm{C}$ is the most aggressive condition, and $\mathrm{U}$ is the condition where severity is not defined fully. According to AS 3600-2001 [86], exposure classes and subclasses were illustrated in table 8 . It relates different exposure conditions with minimum strength requirement and curing requirement. Concrete specification required during supply of concrete were not clearly defined in AS 3600-2001 [86]. Concrete specifications for a particular exposure condition need to be designed considering AS 1379-2007 [87] for parameters such as type of cement, chloride content, sulfate in concrete, air content, strength and exposure conditions in combination with AS 3600-2001 [86]. According to this standard, the acidsoluble chloride content in fresh concrete is restricted to $0.8 \mathrm{~kg} / \mathrm{m}^{3}$ of concrete.

\subsection{Csa a23.1-2009}

CSA A23.1 [88] is a Canadian standard for Concrete Materials and Methods of Concrete Construction. This standard specifies five major exposure categories (extreme chloride, chloride, freezing and thawing, negligible and sulfate) and these categories are further sub-divided into different classes. It describes the respective requirements for each exposure classes such as maximum water binder ratio to be used, minimum compressive strength required, 
Table 9. Summary of exposure classes and their characteristics from different standards.

\begin{tabular}{|c|c|c|c|c|c|c|c|c|c|}
\hline \multirow{3}{*}{$\begin{array}{l}\text { Exposure } \\
\text { classes }\end{array}$} & \multicolumn{4}{|c|}{ Conditions of exposure } & \multicolumn{5}{|c|}{ Minimum and maximum characteristic requirements } \\
\hline & \multirow[b]{2}{*}{ Moisture } & \multirow{2}{*}{$\begin{array}{l}\text { Concrete } \\
\text { condition/ } \\
\text { exposure }\end{array}$} & \multirow{2}{*}{$\begin{array}{l}\text { Chloride } \\
\text { exposure }\end{array}$} & \multirow[b]{2}{*}{ Standard } & \multirow{2}{*}{$\begin{array}{l}\text { Maximum } \\
\mathrm{w} / \mathrm{b}\end{array}$} & \multirow{2}{*}{$\begin{array}{l}\text { Minimum } \\
\text { compressive } \\
\text { strength } \\
(\mathrm{MPa})\end{array}$} & \multicolumn{2}{|c|}{$\begin{array}{l}\text { Chloride } \\
\text { content } \\
\text { limitation } \\
\text { (\% weight } \\
\text { of cement) }\end{array}$} & \multirow{2}{*}{$\begin{array}{l}\text { Performance and } \\
\text { recommendations }\end{array}$} \\
\hline & & & & & & & $\mathrm{RC}$ & PSC & \\
\hline $\mathrm{C} 0$ & Dry & - & $\begin{array}{l}\text { No } \\
\text { chloride }\end{array}$ & $\begin{array}{r}\text { ACI } 318 \\
(2011)\end{array}$ & - & 17.2 & 1.0 & 0.06 & - \\
\hline $\mathrm{C} 1$ & $\begin{array}{l}\text { Slight } \\
\text { exposure }\end{array}$ & - & $\begin{array}{l}\text { No } \\
\text { external } \\
\text { chloride }\end{array}$ & $\begin{array}{r}\text { ACI } 318 \\
(2011)\end{array}$ & - & 17.2 & 0.30 & 0.06 & - \\
\hline $\mathrm{C} 2$ & Severe & - & $\begin{array}{c}\text { Presence } \\
\text { of } \\
\text { external } \\
\text { source } \\
\text { of } \\
\text { chloride }\end{array}$ & $\begin{array}{r}\text { ACI } 318 \\
(2011)\end{array}$ & 0.40 & 34.5 & 0.15 & 0.06 & - \\
\hline $\mathrm{A} 1, \mathrm{~A} 2, \mathrm{U}$ & - & $\begin{array}{c}\text { Ground contact } \\
\text { only }\end{array}$ & - & $\begin{array}{l}\text { AS } \\
3600-2001\end{array}$ & - & $\begin{array}{l}\text { A } 1 \nless 20 ; \\
\text { A } 2 \nless 25 ;\end{array}$ & & - & - \\
\hline $\mathrm{A} 1, \mathrm{~A} 2$ & - & $\begin{array}{l}\text { Interior } \\
\text { environment } \\
\text { exposed } \\
\text { chloride }\end{array}$ & - & $\begin{array}{c}\text { AS } \\
3600-2001\end{array}$ & - & $\begin{array}{l}\text { B } 1 \nless 32 ; \\
\text { B } 2 \nless 40 ;\end{array}$ & & - & \\
\hline $\begin{array}{l}\mathrm{A} 1, \mathrm{~A} 2, \\
\mathrm{~B} 1, \mathrm{~B} 2\end{array}$ & - & Above ground & - & $\begin{array}{c}\text { AS } \\
3600-2001\end{array}$ & - & & & - & \\
\hline $\begin{array}{l}\mathrm{A} 1, \mathrm{~B} 1, \\
\mathrm{~B} 2\end{array}$ & Severe & In water & - & $\begin{array}{l}\text { AS } \\
3600-2001\end{array}$ & - & & & - & \\
\hline $\mathrm{C}-\mathrm{XL}$ & - & - & $\begin{array}{l}\text { Extreme } \\
\text { chloride }\end{array}$ & $\begin{array}{c}\text { CSA A23.1- } \\
2009\end{array}$ & 0.37 & $\begin{array}{l}50 @ \\
56 \text { days }\end{array}$ & & - & $\begin{array}{l}\text { Less than } 1000 \\
\text { coulombs at } \\
56 \text { days, with no } \\
\text { single value } \\
\text { greater than } 1250 \\
\text { coulombs }\end{array}$ \\
\hline C-1/ A-1 & - & - & - & $\begin{array}{c}\text { CSA A23.1- } \\
2009\end{array}$ & 0.40 & $\begin{array}{l}35 @ \\
28 \text { days }\end{array}$ & & - & $\begin{array}{l}\text { Less than } 1500 \\
\text { coulombs at } \\
56 \text { days, with no } \\
\text { single value } \\
\text { greater than } 750 \\
\text { coulombs }\end{array}$ \\
\hline C-2/ A-2 & - & - & - & $\begin{array}{c}\text { CSA A23.1- } \\
2009\end{array}$ & 0.45 & $\begin{array}{l}32 @ \\
28 \text { days }\end{array}$ & & - & - \\
\hline C-3/ A-3 & - & - & - & $\begin{array}{c}\text { CSA A23.1- } \\
2009\end{array}$ & 0.50 & $\begin{array}{l}30 @ \\
28 \text { days }\end{array}$ & & - & - \\
\hline C-4/ A-4 & - & - & - & $\begin{array}{c}\text { CSA A23.1- } \\
2009\end{array}$ & 0.55 & $\begin{array}{l}25 @ \\
28 \text { days }\end{array}$ & & - & - \\
\hline $\mathrm{C}$ & Severs & In water & Extreme & $\begin{array}{c}\text { NZS } 3101-1- \\
2006\end{array}$ & - & - & & - & $\begin{array}{c}2-3.5 \% \text { of Micro } \\
\text { silica; } 3-5.5 \% \text { of } \\
\text { GGBFS }\end{array}$ \\
\hline B2 & - & $\begin{array}{l}\text { Extreme } \\
\text { conditions }\end{array}$ & - & $\begin{array}{c}\text { NZS 3101-1- } \\
2006\end{array}$ & - & - & & - & $\begin{array}{c}0.8-1.2 \% \text { for other } \\
\text { SCMs }\end{array}$ \\
\hline
\end{tabular}

air content permitted, curing type to be adopted for concrete and chloride ion permeability test based on the age. Moreover, chloride penetrability and maximum expansion for chlorides were given based on ASTM C1202 [89]. Based on the chloride exposure, all the requirements are mentioned in table 9. 


\subsection{Europe EN 206-1-2013}

Guidelines and performance requirements to enhance the durability of the concrete was not well defined in the earlier EN 206-1standard [90]. In 2013, "equivalent performance concept" was adopted [90]. Reinforced concrete structures exposed to chloride environment was classified into five sub-classes as XS1, XS2a, XS2b, XS3a and XS3b. The above classifications were based on location, contact, wave action and type of abrasion existing in the specific location. Clear categorization was highlighted based on the exposure of chloride other than in sea environment and separate clauses were defined as XD1, XD2 and XD3.

\subsection{Is en 206-1-2004}

Irish standard for Concrete Specification was developed and modified based on European code EN 206-1 [91]. This standard includes four chloride classes other than exposure conditions, which express the maximum chloride concentration for concrete. The four classes are $C l 1,0 ; C l 0,40 ; C l 0,20$ and $C l 0,10$ where 'comma' represents decimal point and numerical value is maximum chloride ion content in percentage by mass of cement.

\subsection{Indian Standard IS 456-2000}

Indian Standard (IS 456-2000) [92] for Plain Concrete and Reinforced Concrete is similar to other standards and provides different exposure classes. There are five exposure classes considered in the standard (mild, moderate, severe, very severe and extreme). Each exposure condition has been related to minimum requirement of cement, water cement ratio, minimum grade of concrete and concrete cover depth for plain and reinforced concrete. However, the chloride content limit for concrete provided in the standard corresponds to the type of concrete used and not to the exposure conditions. Maximum chloride content was limited to $0.4,0.6$ and $3.0 \mathrm{~kg} / \mathrm{m}^{3}$ of concrete for pre-stressed concrete, reinforced concrete and normal concrete, respectively.

\subsection{Hong Kong Standard of practice for structural use of concrete 2013}

Similar to the Indian standard, Hong Kong Standard has distinguished five exposure conditions (mild, moderate, severe, very severe and abrasive) [93]. In addition, to meet the durability requirement, each exposure condition was related with nominal cover depth, minimum grade of concrete, water binder ratio and minimum cement content. Similar to IS 456:2000 recommendations, Hong Kong Standard also recommends $0.1,0.2$ and 0.35 percentage of chloride ion by mass of concrete for pre-stressed, sulfate resistant and reinforced concretes, respectively.

\subsection{Nzs 3101-1-2006/nzs 3101-2-2006}

New Zealand Standard for Concrete Structure provides various classes for exposure conditions. Total six conditions were specified which were further sub-divided into different exposure classes with respect to contact or exposure of the concrete surface. NZS 3101-1-2006 [94] specified the maximum total chloride content in the concrete. According to the standard, testing for chloride content in concrete should be confirmed either with ASTM C 1152 [95], AS 1012.20 [96] or by using XRF. Moreover, NZS 3101-1-2006 [94] Standard specifies tables for minimum required cover for a specified intended life of 50 and 100 years which is used as an alternative for service life prediction model. These tables provide solution for achieving the desired service life, which is more conservative than the solution derived from the prediction models. Both the proposed tables in the standard are derived from several service-life prediction models as well as real experimental analysis data from marine environment projects. In addition, guidance to the designer regarding the use of initiation model is briefly highlighted. NZS 3101-12006 [94] also recommends maximum acid soluble chloride ion content for different members used in structural design with respect to different exposure conditions. Moreover, it also specifies the surface chloride concentration and diffusion decay index based on different exposure conditions, cementitious materials and chloride threshold value for black steel. Further, maximum soluble chloride ion content $\left(\mathrm{kg} / \mathrm{m}^{3}\right.$ of concrete) as recommended by NZS 3101-1-2006 was given by $0.5,0.8$ and 1.6 respectively for pre-stressed, reinforcement under moisture condition and reinfor-cement under dry or protected from moisture conditions. In this Standard, guidelines are provided for input variables (surface chloride content, diffusion decay index and chloride threshold) to the designer for estimating the corrosion initiation period. In order to perform the comparative performance test, it has recommended two methods: NT BUILD 443v Chloride Diffusion Test and NT BUILD 492 Rapid Migration Test.

\section{Recommendations and suggestions for Indian and international scenario}

The present study reviewed the corrosion mechanism particular to chloride ion ingress and the influential parameters which affect the chloride threshold value and its levels for different conditions. From the study, the recommendations suggested are given below. 
1. Although most service-life prediction models for estimating the period for corrosion initiation require chloride threshold value (CTV), a definitive value including influential parameters is not available in the existing literature. Therefore, clear definitions should be made based on performance specifications as well as factors influencing CTV.

2. Wide range of influential parametric experimental investigation need to be adopted in a systematic manner for attaining reliable specifications for CTV in international Standards. New specifications need to be highlighted in the Standards based on research studies to achieve durable construction practices.

3. No specific method or technique for estimating chloride threshold value is available in the published literature, resulting in misperceptions and very wide ranges of CTV. During construction stage, especially for structures located in marine splash environment where effect of chloride ingress is important, parameters such as surface chloride concentration and initial chloride concentration in atmosphere should be measured periodically and the variations should be accounted for, in estimating CTV.

4. Recommendations based on usage and addition of supplementary materials and its influence on chloride threshold value need to be accounted elaborately. Accurate prediction of CTV for a particular cementitious material can be established and used in on-field conditions. Moreover, replacement level and choice of SCM need to be decided with respect to the required service life and nature of the structure (structures exposed to marine water; off shore structures and structures that are not exposed directly to marine water but to air borne chlorides).

5. A conclusive equation or method describing the effect of initial chloride content on CTV is not recommended by any standard provisions. The initial chloride content and their effects on CTV need to be incorporated in the service life prediction of concrete structures. For instance, ACI 201.2R-01 [85] considers several influential factors and their effects on the chloride content of the fresh concrete mix during construction stage. NZS 3101: 2006 Standards [94] provide equation for calculating the chloride content of the fresh concrete mix based on material characteristics. Similarly, suitable guidelines need to be specified to achieve durable concrete structures.

\section{Conclusions}

Research studies and international standard specifications on chloride threshold value and their influence in the prediction of service life were comprehensively reviewed in this paper. It was observed that precise service life prediction requires an accurate estimation and appropriate measurement of chloride threshold value. Chloride threshold value is treated as a property of the type of steel rebar in most of the service-life prediction models. However, literature reveals that there is wide variation in CTV for the same type of steel, based on exposure conditions and immediate environment. Several parameters are found to influence the chloride threshold value, such as the measurement techniques utilized, supplementary cementitious material used, and many other physical characteristics of the concrete and external environment. Based on a comprehensive review of earlier research studies and specifications from international Standards, the factors that influence the chloride threshold value the suitable recommendations have been highlighted.

\section{References}

[1] Al Hashem A 2011 Corrosion in the gulf cooperation council (GCC) states: statistics and figures. In: Proceedings of Corrosion UAE, Abu Dhabi, UAE

[2] Tang L and Lars-Olof N 1992 Rapid Determination of the chloride diffusivity in concrete by applaying an electrical field. ACI Materials Journal 89(1): 49-53

[3] McGrath P F and Hooton R D 1996 Influence of voltage on chloride diffusion coefficients from chloride migration tests. Cement and Concrete Research 26(8): 1239-1244, https://doi.org/10.1016/0008-8846(96)00094-4.

[4] Angst U 2011 Chloride induced reinforcement corrosion in concrete-Concept of critical chloride content-methods and mechanisms. Norwegian University of Science and Technology, Trondheim

[5] Apostolopoulos C A and Papadakis V G 2008 Consequences of steel corrosion on the ductility properties of reinforcement bar. Construction and Building Materials 22(12): 2316-2324, https://doi.org/10.1016/j.conbuildmat. 2007.10.006

[6] Papadakis V G and Tsimas S 2002 Supplementary cementing materials in concrete: Part I: efficiency and design. Cement and Concrete Research 32(10): 1525-1532, https://doi.org/10.1016/s0008-8846(02)00827-x

[7] Papadakis V G 2000 Effect of supplementary cementing materials on concrete resistance against carbonation and chloride ingress. Cement and Concrete Research 30(2): 291-299, https://doi.org/10.1016/s0008-8846(99)00249-5

[8] Papadakis V G and Apostolopoulos C A 2007 Computeraided approach of parameters influencing concrete service life and field validation. Computers and Concrete 4(1): $1-18$

[9] Zhu X, Zi G, Cao Z and Cheng X 2016. Combined effect of carbonation and chloride ingress in concrete. Construction and Building Materials 110: 369-380, https://doi.org/10. 1016/j.conbuildmat.2016.02.034

[10] Almusallam A A 2001 Effect of degree of corrosion on the properties of reinforcing steel bars. Construction and Building Materials 15(8): 361-368, https://doi.org/10.1016/ s0950-0618(01)00009-5

[11] Papadakis V G, Vayenas C G, Fardis M N 1991 Fundamental modeling and experimental investigation of 
concrete carbonation. ACI Materials Journal 88 M-43(4): 363-373, https://doi.org/10.14359/1863

[12] Papadakis V G, Fardis M N, Vayenas C G 1992 Effect of composition, environmental factors and cement-lime mortar coating on concrete carbonation. Materials and Structures 25(5): 293-304, https://doi.org/10.1007/bf02472670

[13] Papadakis V G 1999 Supplementary cementing materials in concrete-Activity, durability, and planning. Technical Report, Danish Technological University, Taastrup, Denmark

[14] Papadakis V G, Roumeliotis A P, Fardis M N and Vayenas C G 1996 Mathematical modelling of chloride effect on concrete durability and protection measures. In: Dhir, R K, Jones M R (editors) Concrete Repair, Rehabilitation and Protection, Dundee, Scotland: Concrete repair, rehabilitation and protection. London: E. \& F.N. SPON pp. $165-174$

[15] Fang C, Lundgren K, Chen L and Zhu C 2004 Corrosion influence on bond in reinforced concrete. Cement and Concrete Research 34(11): 2159-2167, https://doi.org/10. 1016/j.cemconres.2004.04.006

[16] Allam I M, Maslehuddin M, Saricimen H and Al-Mana A I 1994 Influence of atmospheric corrosion on the mechanical properties of reinforcing steel. Construction and Building Materials 8(1): 35-41, https://doi.org/10.1016/09500618(94)90006-x

[17] Sandberg P 1998 Chloride initiated reinforcement corrosion in marine concrete. Division of Building Materials, LTH, Lund University

[18] Apostolopoulos C 2004 Mechanical behavior of concrete steel bars of monumental structures. In: Proceedings of the Second Panhellenic Conference on Appropriate Interventions for the Safeguarding of Monuments Historical Buildings, Thessaloniki, Greece

[19] Cairns J, Plizzari G A, Du Y, Law D W and Franzoni C 2005 Mechanical properties of corrosion-damaged reinforcement. ACI Materials Journal 102(4): 256-264

[20] Apostolopoulos C A and Papadakis V G 2007 Mechanical behavior of reinforcement stirrups BSt $500 \mathrm{~s}$ at corrosive environment. Journal of Materials Engineering and Performance 16(2): 236-241, https://doi.org/10.1007/s11665007-9038-y

[21] Huang T 2013 The experimental research on the interaction between concrete carbonation and chloride ingress under loading. Zhejiang University, China

[22] Chindaprasirt P, Rukzon S and Sirivivatnanon V 2008 Effect of carbon dioxide on chloride penetration and chloride ion diffusion coefficient of blended Portland cement mortar. Construction and Building Materials 22(8): 1701-1707, https://doi.org/10.1016/j.conbuildmat.2007.06. 002

[23] Wan X M, Wittmann F H, Zhao T J and Fan H 2013 Chloride content and $\mathrm{pH}$ value in the pore solution of concrete under carbonation. J. Zhejiang Univ-Sci. A (Appl Phys \& Eng) 14(1): 71-78, https://doi.org/10.1631/jzus. a1200187

[24] Lee M K, Jung S H and Oh B H 2013 Effects of carbonation on chloride penetration in concrete. ACI Materials Journal 110(5): 559-566

[25] Yoon I 2007 Deterioration of concrete due to combined reaction of carbonation and chloride penetration: experimental study. Key Engineering Materials 348-349: 729-32, https://doi.org/10.4028/www.scientific.net/kem. 348-349.729

[26] McPolin D, Backus J, Long, A, Basheer M, Holmes N 2013. Exposure of mortars to cyclic chloride ingress and carbonation. Advances in Cement Research 25(1): 3-11, https://doi.org/10.1680/adcr.12.00029

[27] Tumidajski, P J and Chan G W 1996. Effect of sulfate and carbon dioxide on chloride diffusivity. Cement and Concrete Research 26(4): 551-556, https://doi.org/10.1016/ 0008-8846(96)00019-1

[28] Yoon I S 2009 Simple approach to calculate chloride diffusivity of concrete considering carbonation. Computers and Concrete 6(1): 1-18

[29] Yuan C, Niu D and Luo D 2012 Effect of carbonation on chloride diffusion in fly ash concrete. Disaster Advances 5(4): 433-436

[30] Delnavaz A and Ramezanianpour A A 2012 The assessment of carbonation effect on chloride diffusion in concrete based on artificial neural network model. Magazine of Concrete Research 64(10): 877-884, https://doi.org/10. 1680/macr.11.00059

[31] Luping T 1997 Chloride penetration profiles and diffusivity in concrete under different exposure conditions. Chalmers University of Technology

[32] Nilsson L O, Poulsen E, Sandberg P, Sorensen H E and Klinghoffer O 1996 HETEK: Chloride penetration into concrete, State-of-the-art, Transport Processes, corrossion initiation, test methods and prediction models. Report No. 53, Danish Road Directorate. Copenhagen, Denmark

[33] Takewaka K and Matsumoto S 1988 Quality and cover thickness of concrete based on the estimation of chloride penetration in marine environments. ACI Special Publication 109(17): 381-400, https://doi.org/10.14359/2124

[34] Maage M, Helland S and Carlsen J E 1993 Chloride penetration in high performance concrete exposed to marine environment. In: Proceedings of the Symposium on Utilization of High Strength Concrete, Lillehammer, Norway

[35] Mangat P S S and Molloy B T T 1994 Predicting of long term chloride concentration in concrete. Materials and Structures 27(6): 338-346, https://doi.org/10.1007/ bf02473426

[36] Bjegović D, Krstić V, Mikulić D and Ukrainczyk V 1995 C-D-c-t diagrams for practical design of concrete durability parameters. Cement and Concrete Research 25(1): 187-196, https://doi.org/10.1016/0008-8846(94)00126-j

[37] Andersen A, Hjelm S, Janz M, Johannesson B, Pettersson K and Sandberg P 1998 Total chloride profiles in uncracked concrete exposed at Translovslage marine filed stationRaw data from 1992-1997. Lund, Sweden.

[38] DuraCrete 2000 DuraCrete Final Report, EU-Brite Euram III

[39] Luping T and Nilsson L O 2000 Modeling of chloride penetration into concrete-Tracing five years' field exposure. Concrete Science and Engineering 2: 170-175

[40] Hausmann D A 1967 Steel corrosion in concrete: How does it occur? Journal of Materials Protection 19-23

[41] Alonso C, Andrade C and González J A 1988 Relation between resistivity and corrosion rate of reinforcements in carbonated mortar made with several cement types. Cement 
and Concrete Research 18(5): 687-698, https://doi.org/10. 1016/0008-8846(88)90091-9

[42] Feliu S, González J A, Feliu S and Andrade C 1989 Relationship between conductivity of concrete and corrosion of reinforcing bars. British Corrosion Journal 24(3): 195-198, https://doi.org/10.1179/000705989798270027

[43] Glass G K, Page C L and Short N R 1991 Factors affecting the corrosion rate of steel in carbonated mortars. Corrosion Science 32(12): 1283-1294, https://doi.org/10.1016/0010938x(91)90048-t

[44] Andrade C, Alonso C and Goni S 1993 Possibilities for electrical resistivity to universally characterize mass transport processes in concrete. In: Dhir, R K, Jones, M R (editors) Concrete 2000 Economic and Durable Construction Through Excellence Volume Two: Infrastructure, Research, New Applications, E \& FN Spon pp. 1639-1652

[45] López W and González J A 1993 Influence of the degree of pore saturation on the resistivity of concrete and the corrosion rate of steel reinforcement. Cement and Concrete Research 23(2): 368-376, https://doi.org/10.1016/00088846(93)90102-f

[46] Andrade C and Alonso C 1996 Corrosion rate monitoring and on-site. Construction and Building Materials 10(5): 315-328

[47] Hussain S E, Rasheeduzzafar, Al-Musallam A and AlGahtani A S 1995 Factors affecting threshold chloride for reinforcement corrosion in concrete. Cement and Concrete Research 25(7): 1543-1555, https://doi.org/10.1016/00088846(95)00148-6

[48] Mammoliti L T, Brown L C, Hansson C M and Hope B B 1996 The influence of surface finish of reinforcing steel and $\mathrm{pH}$ of the test solution on the chloride threshold concentration for corrosion initiation in synthetic pore solutions. Cement and Concrete Research 26(4): 545-550, https://doi. org/10.1016/0008-8846(96)00018-x

[49] Petterson K 1992 Corrosion threshold value and corrosion rate in reinforced concrete. Swedish Cement and Concrete Research Institute. vol. 2, Stockholm, Sweden

[50] Gouda V K 1970 Corrosion and Corrosion Inhibition of Reinforcing Steel: I. Immersed in Alkaline Solutions. British Corrosion Journal 5(5): 198-203, https://doi.org/10. 1179/000705970798324450

[51] Diamond S 1981 Effects of two Danish fly ashes on alkali contents of pore solutions of cement-fly ash pastes. Cement and Concrete Research 11(3): 383-394

[52] Byfors K 1987 Influence of silica fume and flyash on chloride diffusion and $\mathrm{pH}$ values in cement paste. Cement and Concrete Research 17(1): 115-130, https://doi.org/10. 1016/0008-8846(87)90066-4

[53] Thomas M 1996 Chloride Threshold in marine concrete. Cement and Concrete Research 26(4): 513-519

[54] Whiting D A, Taylor P C and Nagi M 2002 Chloride Limits in Reinforced Concrete. Portland Cement Association. R\&D Serial No. 2438, Skokie, Illinois, USA, pp. 1-76

[55] Hansson C M, Sørensen B 1989 The Threshold value of chloride concentration for the corrosion of reinforcement in concrete. In: Berke N S, Chaker, V and Whiting D (editors) Corrosion Rates of Steel in Concrete, vol. STP 1065. pp. 3-16

[56] Larsen C K 1998 Chloride binding in concrete. Norwegian University of Science and Technology, NTNU
[57] Oh B H, Jang S Y and Shin Y S 2003 Experimental investigation of the threshold chloride concentration for corrosion initiation in reinforced concrete structures. Magazine of Concrete Research 55: 117-124

[58] Castellote M, Andrade C and Alonso C 2002 Accelerated simultaneous determination of the chloride depassivation threshold and of the non-stationary diffusion coefficient values. Corrosion Science 44(11): 2409-2424, https://doi. org/10.1016/s0010-938x(02)00060-4

[59] Lambert P, Page C L and Vassie P R W 1991 Investigations of reinforcement corrosion. 2. Electrochemical monitoring of steel in chloride-contaminated concrete. Materials and Structures 24(5): 351-358

[60] Dhir R K, El-Mohr M A K and Dyer T D 1996 Chloride binding in GGBS concrete. Cement and Concrete Research 26(12): 1767-73, https://doi.org/10.1016/s00088846(96)00180-9

[61] Richartz W 1969 Die Bindung von Chlorid bei der Zementerh\{ä\}rtung. Zement-Kalk-Gips 22(10): 447-456

[62] Puatatsananon W and Saouma V E 2005 Nonlinear coupling of carbonation and chloride diffusion in concrete. Journal of Materials in Civil Engineering 17(3): 264-275, https://doi.org/10.1061/(asce)0899-1561(2005)17:3(264)

[63] Phares B M, Fanous F S, Wipf T J, Lee Y S and Jolley M J 2006 CTRE Project 02-103: Evaluation of corrosion resistance of different steel reinforcement types. Center for Transportation Research and Education. Iowa State University

[64] Sagüés A A, Powers R G and Kessler R 1995 An update on corrosion processes and field performance of epoxy coated reinforcing steel. COST-509 In: Workshop of Corrosion and Protection of Metals in Contact with Concrete, Houston: NACE International

[65] Mohammed T and Hamada H 2006 Corrosion of steel bars in concrete with various steel surface conditions. ACI Materials Journal 103(103): 233-242

[66] Locke C E and Siman A 1980 Electrochemistry of Reinforcing Steel in Salt-Contaminated Concrete. ASTM Selected Technical Paper. https://doi.org/10.1520/stp27465s

[67] Breit W 1998 Critical chloride content-investigations of steel in alkaline chloride solutions. Materials and Corrosion 49: 539-550

[68] Alonso C, Andrade C, Castellote M and Castro P 2000 Chloride threshold values to depassivate reinforcing bars embedded in a standardized OPC mortar. Cement and Concrete Research 30(7): 1047-1055, https://doi.org/10. 1016/s0008-8846(00)00265-9

[69] Alonso C, Castellote M and Andrade C 2002 Chloride threshold dependence of pitting potential of reinforcements. Electrochimica Acta 47(21): 3469-3481, https://doi.org/10. 1016/s0013-4686(02)00283-9

[70] Ann K Y and Song H W 2007 Chloride threshold level for corrosion of steel in concrete. Corrosion Science 49(11): 4113-4133

[71] Deb S 2012 Critical chloride content in reinforced concrete. The Materbuilder 9

[72] Basham K 1999 Choices in corrosion-resistant rebar. Concrete Construction 44(10): 27-33

[73] McKeel W T 1993 Report Number: FHWA/VA-94-R5 Evaluation of epoxy-coated reinforcing steel. Final report, Virginia Transportation Research Council, Virginia 
[74] Lau K 2010 Corrosion of epoxy-coated reinforcement in marine bridges with locally deficient concrete by University of South Florida

[75] Lee S K 2012 Bridge deterioration: Part 2-Bridge deterioration caused by corrosion. Materials Performance Journal 51(2)

[76] Alonso C, Recio F J, Sanchez M and Andrade C 2008 Chloride threshold determination in prestressing steel beams. In: 11DBMC International Conference on Durability of Building Materials and Components, Istanbul, Turkey

[77] Pfeifer D W, Perenchio W F and Hime W G 1992 A critique of the ACI 318 chloride limits. PCI Journal 37(2): $68-71$

[78] Azuma Y, Miyazato S, Niitani K, Yamada K and Tokumitu S 2007 Influence of chloride ion content and stress on steel corrosion in cement paste grout. In: 32nd Conference on Our World in Concrete and Structures, Singapore, Singapore

[79] Trejo D and Pillai R G 2003 Accelerated choride threshold testing: Part 1-ASTM A615 and A706 Reinforcement. ACI Materials Journal November/D(6): 519-527

[80] Trejo D and Pillai R G 2004 Accelerated chloride threshold testing-Part II: Corrosion-resistant reinforcement. ACI Materials Journal 101(1): 57-64, https://doi.org/10.14359/ 12988

[81] Hope B B and Ip A K C 1987 Chloride corrosion threshold in concrete. ACI Materials Journal 84(4): 306-314

[82] Elsener B and Böhni H 1986 Corrosion of steel in mortar studied by impedance measurements. Materials Science Forum 8: 363-372, https://doi.org/10.4028/www.scientific. net/msf.8.363

[83] Manera M, Vennesland $\varnothing$ and Bertolini L 2008 Chloride threshold for rebar corrosion in concrete with addition of silica fume. Corrosion Science 50(2): 554-560, https://doi. org/10.1016/j.corsci.2007.07.007

[84] ACI 318M-14 2014 Building Code Requirements for Structural Concrete

[85] ACI 201.2R-01 2001 Guide to durable concrete. American Concrete Institute, Committee

[86] AS 3600-2001 2001 Concrete structures. 3rd ed

[87] AS 13792007 Specification and supply of concrete. Australian Standard (1): 1-53

[88] CSA 2009 CSA A23.1-09/A23.2-09: Concrete materials and methods of concrete construction/test methods and standard practices for concrete. CSA Group

[89] ASTM C1202 2012 Standard Test Method for Electrical Indication of Concrete's Ability to Resist Chloride Ion Penetration. American Society for Testing and Materials: 1-8, https://doi.org/10.1520/c1202-12.2

[90] BS EN 206-1:2000 2000 Specification, performance, production and conformity. British Standards.

[91] EN206-1 2004 The new Concrete Standards. Dublin

[92] Bureau of Indian Standard (BIS) 2000 Plain and reinforced concrete-code of practice. IS 456(4th Rev.) (July): New Delhi, India

[93] Code of practice for structural use of concrete 2013. Hong Kong

[94] NZS 3101-Part 1., 2006. Concrete structures standard, Part 1-The design of concrete structures. Standards Council, Concrete Design Committee, P-3101: 697
[95] ASTM C1152/C1152M-04(2012) 2012 Standard test method for acid-soluble chloride in mortar and concrete

[96] AS 1012.20-1992 1992 Methods of testing concrete. Australian Standard: 1-2

[97] Schiessl P and Breit W 1996 Local repair measures at concrete structures damaged by reinforcement corrosionaspects of durability. In: 4th Int. Symp. "Corrosion of Reinforcement in Concrete Construction," Cambridge: The Royal Society of Chemistry, pp. 525-534

[98] Zimmermann L, Elsener B and Böhni H 2000 Critical factors for the initiation of rebar corrosion. Corrosion of reinforcement in concrete: Corrosion mechanisms and corrosion protection. Papers from EUROCORR '99, vol. Number 31. Aachen, Germany, pp. 25-34

[99] Schiessl P and Raupach M 1990 Influence of concrete composition and microclimate on the critical chloride content in concrete. In: Proc. 3rd Int. Symp. "Corrosion of Reinforcement in Concrete", Elsevier Applied Science, Wishaw, UK, pp. 49-58

[100] Takage N 1991 Chloride corrosion of reinforcing steel in silica fume concrete exposed to marine environment. In: Malhotra S K (editor) Special Publication, vol. 126. ACI, Detroit, pp. 479-498

[101] Nygaard P V 2005 A method for measuring the chloride threshold level required to initiate reinforcement corrosion in concrete. Materials and Structures 38(278): 489-494, https://doi.org/10.1617/14279

[102] Clear K C 1976 Time-to-corrosion of reinforcing steel in concrete slabs. Transportation Research Record (500):16-24

[103] Sohanghpurwala A A and Scannell W T 1998 Verification of effectiveness of epoxy coated rebars. Harrisburg, PA

[104] Fanous F S and Wu H C 2000 Service life of iowa bridge decks reinforced with epoxy-coated bars. In: Mid-Continent Transportation Symposium 2000, pp. 259-262

[105] Darwin D J, Browning T V, Van Nguyen T and Locke C E 2002 Mechanical and corrosion properties of a highstrength, high chromium reinforcing steel for concrete. Kansas

[106] O'Reilly M, Darwin D, Browning J, Locke C E 2012 Evaluation of multiple corrosion protection systems for reinforced concrete bridge decks. Structural Engineering and Engineering Materials SM Report No. 100, The university of Kansas center for research, Inc., Lawrence, Kansas

[107] Lawler J S, Kurth J C and Krauss D P 2015 Statistical distributions for chloride thresholds of carbon steel and epoxy coated reinforcing bars for probabilistic service life modeling. In: Concrete Service life Extension Conference, Philadelphia

[108] Stark D 1984 Determination of permissible chloride levels in prestressed concrete. Prestressed Concrete Institute 29(4): 106-119

[109] Life S 1999 High performance concrete and reinforcing steel with a. Precast/Prestressed Concrete Institute (PCI) Journal: $46-54$

[110] Wang H B, Sagues A A and Powers R G 2005 Corrosion of the strand- anchorage system in post-tensioned grouted assemblies title. In: NACE International Corrosion Conference, Houston, TX 
[111] Alonso C, Recio F J, Sanchez M and Andrade C 2008 International symposium on durability of building materials and components. In: Nil A and Ozkan S (editors) Proc. EUROCORR '99, Istanbul p. 463

[112] Trejo D, Beth M H D, Gardoni P, Pillai R G, Reinschmidt K, Seok B I, Kataria S, Hurlebaus S, Gamble M, Ngo T T 2009 Report No. FHWA/TX-09/0-4588-1 Effect of Voids in Grouted, Post-Tensioned Concrete Bridge Construction: Volume 1 - Electrochemical Testing and Reliabililty Assessment, Texas Transportation Institute, Austin, Texas

[113] Stratfull R F 1975 Corrosion Testing of Bridge Decks. Transportation Research Record (539):50-59
[114] Lukas W 1985 Relationship between chloride content in concrete and corrosion in untensioned rein-forcement on Austrian bridges and concrete road surfacings, Betonwerk und Fertigteil-Technik, 51(11): 730-734

[115] Goni S and Andrade C 1990 Synthetic concrete pore solution chemistry and rebar. Cement and Concrete Research 20(c): 525-539

[116] Thomas M D A, Matthews J D and Haynes C A 1990 Chloride diffusion and reinforcement corrosion in marine exposed concrete containing pulverized-fuel ash. In: Proc. 3rd Int. Symp. "Corrosion of Reinforcement in Concrete," Elsevier Applied Science, Wishaw, pp. 198-212 